\title{
A new genus of the order Actinomycetales, Virgosporangium gen. nov., with descriptions of Virgosporangium ochraceum sp. nov. and Virgosporangium aurantiacum sp. nov.
}

\footnotetext{
1 Institute for Fermentation, Osaka, 2-17-85 Jusohonmachi Yodogawa-ku, Osaka 532-8686, Japan

2 Department of Applied Chemistry and Biotechnology, Faculty of Engineering, Yamanashi University, 4-3-11 Takeda, Kofu, Yamanashi 400-8510, Japan
}

\author{
Tomohiko Tamura, ${ }^{1}$ Masayuki Hayakawa² and Kazunori Hatano ${ }^{1}$ \\ Author for correspondence: Tomohiko Tamura. Tel: +8166300 6555. Fax: +81663006814. \\ e-mail: tamura-tomohiko@ifo.or.jp
}

\begin{abstract}
Four motile spored strains were isolated from soil samples collected in Japan. The cultures formed long, narrow sporangia on short sporangiophores directly on the substrate mycelium. The sporangia develop singly or in clusters above the surface of the substrate. Each sporangium contains a single row of six or more motile spores. Glutamic acid, glucosamine, glycine, alanine and 3-OHdiaminopimelic acid are present in the cell wall; the whole-cell sugars are 3-0methylmannose, rhamnose, mannose, arabinose, galactose, xylose and glucose; and the predominant menaquinones are $10\left(\mathrm{H}_{4}\right), 10\left(\mathrm{H}_{6}\right)$ and $10\left(\mathrm{H}_{8}\right)$. The diagnostic phospholipid is phosphatidylethanolamine. The acyl type of the muramic acid is glycolyl. The G+C content is $71 \mathrm{~mol} \%$. Mycolic acids are absent. The chemotaxonomic data indicate that these strains belong to the family Micromonosporaceae. Analysis of 16S rDNA sequences suggested that these organisms fall into a distinct clade within the family Micromonosporaceae for which a new genus, Virgosporangium gen. nov., is proposed containing the species Virgosporangium ochraceum sp. nov. (strains YU655-43', YU793-41 and YU794-41) and Virgosporangium aurantiacum sp. nov. (strain YU438-5').
\end{abstract}

\section{INTRODUCTION}

The family Micromonosporaceae Krasil'nikov 1938 was originally created on a morphological basis. Goodfellow et al. (1990) emended the family and added the genera Actinoplanes, Dactylosporangium and Pilimelia on the basis of numerical and chemical analyses. The genera Catenuloplanes (Yokota et al., 1993) and Couchioplanes (Tamura et al., 1994) were subsequently added on the basis of phylogenetic analysis. Koch et al. (1996) emended the description of the family to reflect its phenotypic and chemotaxonomic heterogeneity. Later, Stackebrandt et al. (1997) emended the family on the basis of $16 \mathrm{~S}$ rDNA/rRNA sequence phylogenetic clustering and

\footnotetext{
The GenBank accession numbers for the 165 rDNA sequences determined in this work are: AB006167 (Virgosporangium ochraceum YU655-43'), AB006162 (Virgosporangium ochraceum YU793-41), AB006161 (Virgosporangium ochraceum YU794-41) and AB006169 (Virgosporangium aurantiacum YU438-5 $5^{\top}$.
}

the presence of taxon-specific 16S rDNA/rRNA signature nucleotides.

During taxonomic studies of rare actinomycetes, four strains have been isolated, YU438- $5^{\mathrm{T}}$, YU655-43 ${ }^{\mathrm{T}}$, YU793-41 and YU794-41, from soil samples from Yamanashi and Okinawa prefectures, Japan. These strains produce sporangia that typically contain a single row of six or more motile spores, and have 3$\mathrm{OH}$-diaminopimelic acid and glycine in the cell wall. On the basis of their 16S rDNA sequences, the isolates phylogenetically fall within the family Micromonosporaceae, but form a lineage distinct from described organisms. Therefore, we propose that the isolates should be included in a new genus, Virgosporangium, the name being derived from the virgate sporangia of the organism.

\section{METHODS}

Micro-organisms and culture conditions. Strains YU438- $5^{\mathrm{T}}$ $\left(=\mathrm{IFO} 16421^{\mathrm{T}}\right)$ and YU655-43 ${ }^{\mathrm{T}}\left(=\mathrm{IFO} 16418^{\mathrm{T}}\right)$ were 

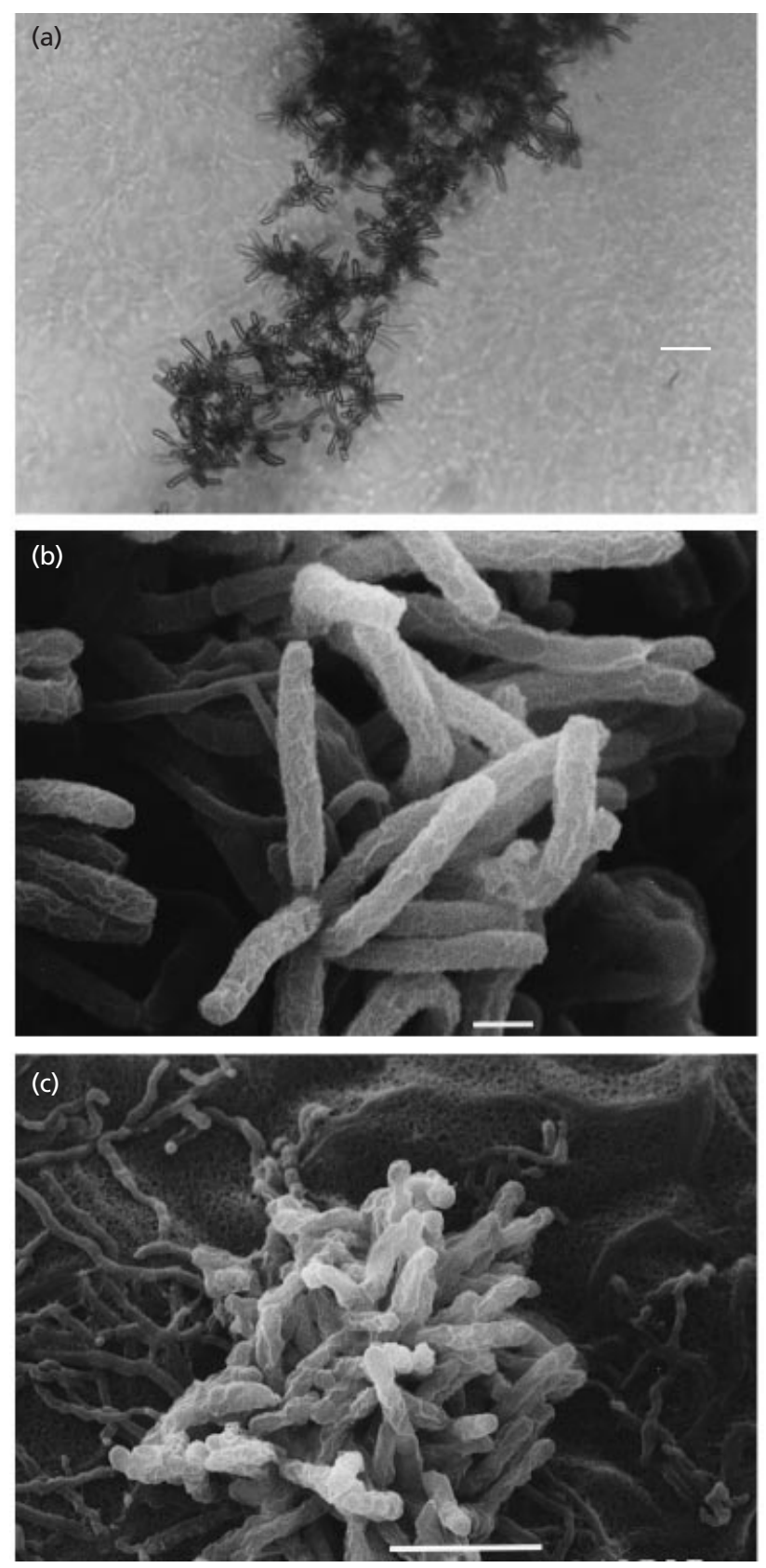

Fig. 1. Light micrograph (a) and scanning electron micrograph (b) of isolate YU655-43 ${ }^{\top}$, and scanning electron micrograph of isolate $\mathrm{YU} 438-5^{\top}$ (c) grown on yeast extract-starch agar agar for 2 weeks at $28^{\circ} \mathrm{C}$. Bars: (a) $10 \mu \mathrm{m}$, (b) $1 \mu \mathrm{m}$, (c) $5 \mu \mathrm{m}$.

isolated from a soil sample from a vegetable field in Yamanashi prefecture, strain YU793-41 (= IFO 16419) was isolated from a soil sample from a mulberry field in Okinawa prefecture, and YU794-41 (= IFO 16420) was isolated from a soil sample from a potato field in Okinawa prefecture, Japan. All were isolated on humic acid-vitamin (HV) agar (Hayakawa \& Nonomura, 1987) by the capillary method (Palleroni, 1980; Hayakawa et al., 1992) using vanillin as an attractant. Freeze-dried cells for chemotaxonomic analyses were grown in yeast extract-glucose broth $(10 \mathrm{~g}$ yeast extract, $10 \mathrm{~g}$ D-glucose per litre distilled water, $\mathrm{pH} 7 \cdot 0$ ) on a rotary shaker at $28^{\circ} \mathrm{C}$. Actinoplanes philippinensis IFO $13878^{\mathrm{T}}$, Dactylosporangium thailandense IFO $12593^{\mathrm{T}}$, Micromonospora chalcea IFO $13503^{\mathrm{T}}$ and Catellatospora citrea subsp. citrea IFO $14495^{\mathrm{T}}$ were analysed to compare whole-cell sugar patterns.

Cultural, morphological and physiological characteristics. Cultures grown on HV agar and yeast extract-starch agar (containing $2 \mathrm{~g}$ yeast extract and $10 \mathrm{~g}$ soluble starch per litre distilled water, $\mathrm{pH} 7 \cdot 0$ ) for $3-14 \mathrm{~d}$ at $28^{\circ} \mathrm{C}$ were observed with a light microscope and with a scanning electron microscope (model JSM-5400; JEOL). Samples for scanning electron microscopy were prepared by cutting a block from an agar plate containing the strain, fixing the block in osmium tetroxide vapour at room temperature for $4 \mathrm{~h}$, dehydrating the cells by freeze-drying and then sputtercoating them with palladium under vacuum.

Motility was observed with a light microscope using cells grown on $\mathrm{HV}$ agar for $7-10 \mathrm{~d}$ at $28^{\circ} \mathrm{C}$, then incubated at $28^{\circ} \mathrm{C}$ for $30-60 \mathrm{~min}$ in sterile water. Cultural characteristics on media according to the International Streptomyces Project (ISP) (Shirling \& Gottlieb, 1966) and on nutrient agar (Difco) were recorded after $14 \mathrm{~d}$ incubation at $28^{\circ} \mathrm{C}$. Colours are described in common terminology, and colours were also determined more exactly by comparison with the colour chips given by Rayner (1970).

Physiological characteristics were determined according to Seino et al. (1985). ISP medium 9 was used as a basal medium to examine utilization of sugars. Inorganic saltsstarch agar (ISP medium 4) was used to determine starch hydrolysis. Growth temperature was determined on yeast extract-starch agar. Calcium malate medium (10 g calcium malate, $0.5 \mathrm{~g} \mathrm{NH}_{4} \mathrm{Cl}, 0.5 \mathrm{~g} \mathrm{~K}_{2} \mathrm{HPO}_{4}, 18 \mathrm{~g}$ agar per litre distilled water, $\mathrm{pH} \mathrm{7.0)}$ ) was used to determine solubility of calcium malate. ISP medium 8 was used to determine nitrate reduction. Gelatin medium (200 g gelatin per litre distilled water, $\mathrm{pH} 7 \cdot 0)$ and glucose-peptone-gelatin medium $(20 \mathrm{~g}$ glucose, $5 \mathrm{~g}$ peptone and $200 \mathrm{~g}$ gelatin per litre distilled water, $\mathrm{pH} 7 \cdot 0$ ) were used to determine gelatin liquefaction. Skim milk $(10 \%, \mathrm{w} / \mathrm{v}$; Difco) was used for determination of coagulation and peptonization of milk.

Analyses of chemotaxonomic characteristics. Analyses of whole-cell sugar patterns, cell wall amino acids, menaquinones, cellular fatty acids, isomers of diaminopimelic acid, acyl type of the peptidoglycan, mycolic acid and DNA base composition were performed as described previously (Tamura et al., 1994).

Preparation of DNA and determination of $\mathbf{G}+\mathbf{C}$ content. Genomic DNA was prepared according to the method of Ezaki et al. (1990). The $\mathrm{G}+\mathrm{C}$ content of the DNA was determined by the method of Mesbah et al. (1989) after treatment with P1 nuclease and alkaline phosphatase, and by HPLC using a Shimadzu LC-6AD apparatus equipped with a column of Cosmosil 5C18-AR $(4.6 \times 150 \mathrm{~mm}$; Nacalai Tesque).

PCR amplification and sequencing of 16S rDNA. 16S rDNA was amplified by PCR and the resulting products directly sequenced using previously described protocols (Tamura et al., 1998). The products were analysed with a Pharmacia ALF DNA Sequencer II according to the manufacturer's protocol.

Phylogenetic analysis. 16S rDNA sequences of the strains and reference organisms were aligned with that of Streptomyces ambofaciens (Pernodet et al., 1989). The CLUSTAL w version 1.7 software package (Thompson et al., 1994) was used to generate the evolutionary distances (the $K_{\text {nuc }}$ value of 
Table 1. Cultural characteristics of isolates $Y U 438-5^{\top}$ and $Y U 655-43^{\top}$

YU793-41 and YU794-41 showed cultural characteristics similar to those of YU655-43 .

\begin{tabular}{|c|c|c|c|c|}
\hline \multirow[t]{2}{*}{ Medium } & \multicolumn{2}{|c|}{${\text { YU } 438-5^{\mathrm{T}}}^{-}$} & \multicolumn{2}{|c|}{ YU655-43 } \\
\hline & Growth & Colour* & Growth & Colour* \\
\hline $\begin{array}{l}\text { Yeast extract-malt extract } \\
\text { agar (ISP medium 2) }\end{array}$ & Moderate & $\begin{array}{l}\text { Strong vivid reddish } \\
\text { orange }(5)\end{array}$ & Good & Strong orange (7) \\
\hline Oat meal agar (ISP medium 3) & Good & Strong orange $(7)$ & Moderate & Strong orange (7) \\
\hline $\begin{array}{l}\text { Inorganic salts-starch } \\
\text { agar (ISP medium 4) }\end{array}$ & Moderate & Strong orange (7) & Poor & Colourless \\
\hline $\begin{array}{l}\text { Glycerol-asparagine } \\
\text { agar (ISP medium 5) }\end{array}$ & Moderate & Strong orange (7) & Poor & Colourless \\
\hline $\begin{array}{l}\text { Peptone-yeast extract iron } \\
\text { agar (ISP medium 6) }\end{array}$ & Moderate & Strong orange (7) & Moderate & $\begin{array}{l}\text { Moderate } \\
\text { orange-yellow (44) }\end{array}$ \\
\hline $\begin{array}{l}\text { Tyrosine agar } \\
\text { (ISP medium 7) }\end{array}$ & Moderate & $\begin{array}{l}\text { Moderate reddish } \\
\text { brown (60) to } \\
\text { moderate brown } \\
(63) ; \text { moderate } \\
\text { brown (87) soluble } \\
\text { pigment }\end{array}$ & Moderate & $\begin{array}{l}\text { Moderate brown } \\
(87) \text {; greyish } \\
\text { reddish orange (59) } \\
\text { to moderate } \\
\text { brown (87) soluble } \\
\text { pigment }\end{array}$ \\
\hline Nutrient agar & Moderate & Strong orange (7) & Moderate & $\begin{array}{l}\text { Moderate } \\
\text { orange-yellow (44) }\end{array}$ \\
\hline
\end{tabular}

* Numbers in parentheses correspond to the colour chips given by Rayner (1970).

Table 2. Cellular fatty acid compositions (\%) of isolates YU438-5', YU655-43', YU793-41 and YU794-41

\begin{tabular}{|c|c|c|c|c|}
\hline Fatty acid & YU438-5 & YU655-43 ${ }^{\mathrm{T}}$ & YU793-41 & YU794-41 \\
\hline \multicolumn{5}{|l|}{ Iso-branched } \\
\hline $\mathrm{C}_{15: 0}$ & $5 \cdot 9$ & $10 \cdot 3$ & $10 \cdot 5$ & $9 \cdot 6$ \\
\hline $\mathrm{C}_{16: 0}^{100}$ & $27 \cdot 9$ & $12 \cdot 6$ & $6 \cdot 8$ & $18 \cdot 2$ \\
\hline $\mathrm{C}_{17: 0}$ & $6 \cdot 1$ & $5 \cdot 4$ & $7 \cdot 8$ & 6 \\
\hline \multicolumn{5}{|c|}{ Anteiso-branched } \\
\hline $\mathrm{C}_{15: 0}$ & 1.9 & $2 \cdot 9$ & $1 \cdot 8$ & $1 \cdot 2$ \\
\hline $\mathrm{C}_{17: 0}$ & $28 \cdot 8$ & $21 \cdot 3$ & $16 \cdot 4$ & $11 \cdot 9$ \\
\hline \multicolumn{5}{|l|}{ Saturated } \\
\hline $\mathrm{C}_{14: 0}$ & & & $0 \cdot 6$ & \\
\hline $\mathrm{C}_{15: 0}$ & & $2 \cdot 5$ & $1 \cdot 5$ & $2 \cdot 4$ \\
\hline $\mathrm{C}_{16: 0}^{100}$ & $1 \cdot 4$ & $2 \cdot 4$ & $4 \cdot 6$ & $2 \cdot 2$ \\
\hline $\mathrm{C}_{17: 0}^{10.0}$ & $5 \cdot 6$ & $8 \cdot 8$ & $8 \cdot 4$ & $11 \cdot 1$ \\
\hline $\mathrm{C}_{18: 0}$ & $4 \cdot 3$ & $1 \cdot 8$ & $7 \cdot 7$ & $2 \cdot 2$ \\
\hline $\mathrm{C}_{19: 0}$ & $1 \cdot 6$ & $1 \cdot 3$ & $2 \cdot 4$ & $1 \cdot 6$ \\
\hline \multicolumn{5}{|l|}{ Unsaturated } \\
\hline $\mathrm{C}_{17: 1}$ & $3 \cdot 4$ & $8 \cdot 9$ & $2 \cdot 2$ & $7 \cdot 8$ \\
\hline $\mathrm{C}_{18: 1}^{18.1}$ & $9 \cdot 1$ & $13 \cdot 4$ & $19 \cdot 2$ & $14 \cdot 4$ \\
\hline $\begin{array}{l}\mathrm{C}_{19: 1}^{18: 1} \\
\end{array}$ & $3 \cdot 3$ & $8 \cdot 5$ & $8 \cdot 3$ & $11 \cdot 6$ \\
\hline Unidentified & $0 \cdot 8$ & & $2 \cdot 0$ & \\
\hline
\end{tabular}

Kimura, 1980) and the similarity values and for the neighbour-joining (NJ) analysis (Saitou \& Nei, 1987) from $K_{\text {nuc }}$ values. The topology of the phylogenetic tree was evaluated by the bootstrap resampling method of Felsenstein (1985) with 1000 replicates. NJplot (Perrière \& Gouy, 1996) was used for constructing the phylogenetic tree.
The GenBank accession numbers for the 16S rDNA sequences determined in this work are: AB006169 (strain YU438-5 ${ }^{\mathrm{T}}$ ), AB006167 (strain YU655-43 ${ }^{\mathrm{T}}$ ), AB006162 (strain YU793-41) and AB006161 (strain YU794-41).

DNA-DNA hybridization. To determine DNA relatedness, the microplate-hybridization method developed by Ezaki et 


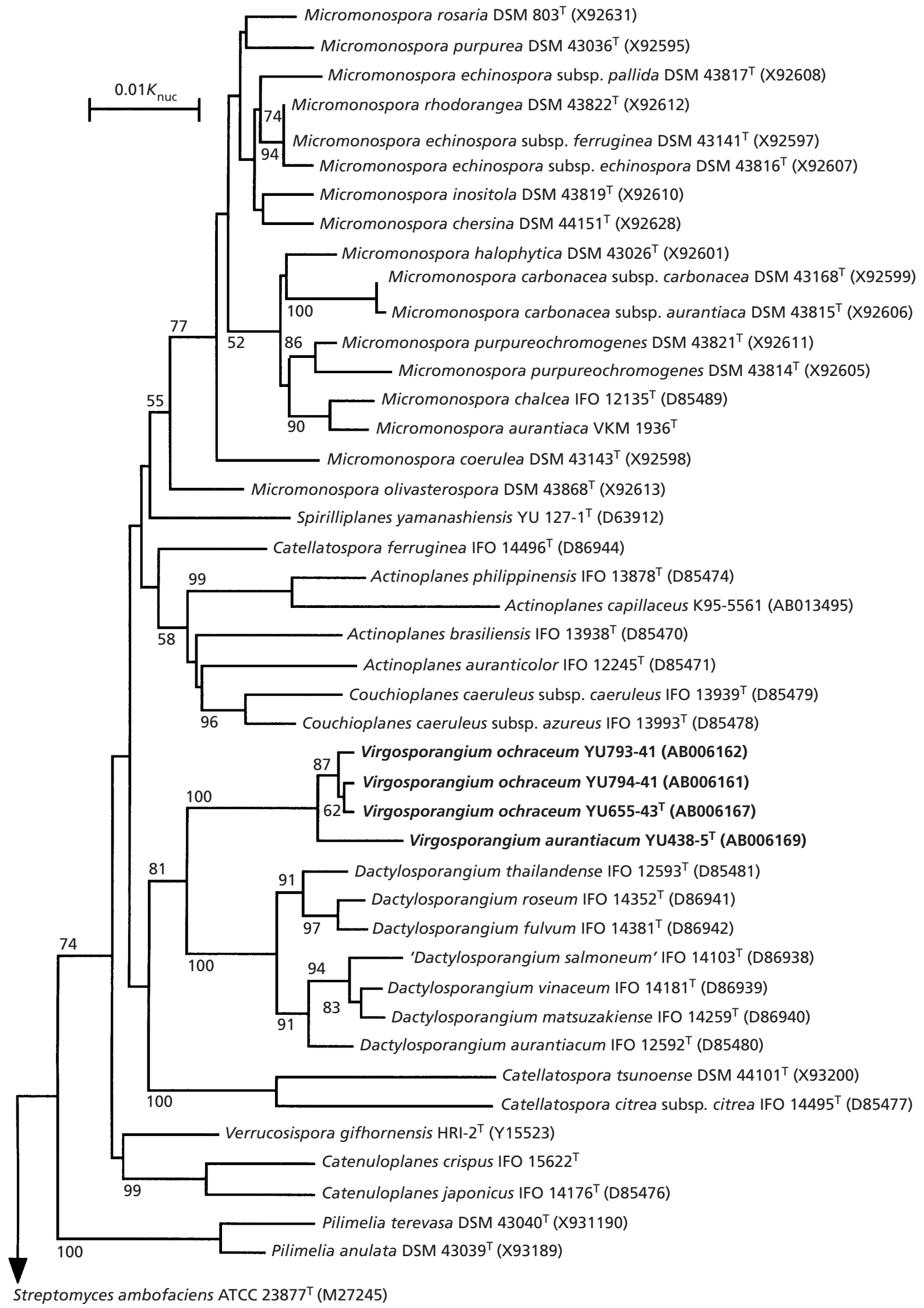

Fig. 2. For legend see facing page. 
al. $(1988,1989)$ was applied with minor modifications (Tamura et al., 1999).

\section{RESULTS}

\section{Morphological observations}

Micrographs of 14-d-old cultures of isolates grown on HV agar are shown Fig. 1. The isolates formed rodshaped sporangia on the substrate mycelium, which developed singly or in clusters above the surface of the substrate. Under the scanning electron microscope (Fig. 1b), each sporangium was seen to typically contain a single row of six spores or more. Globose bodies were not observed. Spores were oval to short rods $(0.6-0.9$ by $0.8-1.5 \mu \mathrm{m})$. After incubation at $28^{\circ} \mathrm{C}$ for $1 \mathrm{~h}$ in distilled water, many spores exhibited active motility.

\section{Cultural characteristics}

Strain YU438- $5^{\mathrm{T}}$ developed scarlet to orange colonies on ISP media 2, 3, 4, 5 and 6, and on nutrient agar, and the other strains developed orange to rust colonies on ISP media 2, 3 and 6, and on nutrient agar (Table 1). All isolates produced a brownish soluble pigment on ISP medium 7. Aerial mycelium rarely developed on colonies growing on either HV agar or water agar.

\section{Physiological and biochemical characteristics}

All isolates utilized glucose, saccharose, D-fructose, Dmannitol, L-arabinose, glycerol, galactose and mannose. Only strain YU655-43 ${ }^{\mathrm{T}}$ utilized inositol and Dsorbitol; only strain YU438- $5^{\mathrm{T}}$ utilized lactose; strains YU438-5 $5^{\mathrm{T}}$ and YU655-43 ${ }^{\mathrm{T}}$ utilized melibiose; only strain YU793-41 did not utilize maltose. All isolates were positive for hydrolysis of starch, coagulation and peptonization of milk, and formation of nitrite from nitrate, and were negative for decomposition of calcium malate and gelatin liquefaction. Strain YU438-5 ${ }^{\mathrm{T}}$ grew at $15-30^{\circ} \mathrm{C}$ but not at $37^{\circ} \mathrm{C}$, while strains YU655-43 ${ }^{\mathrm{T}}$, YU793-41 and YU794-41 grew at $15-37^{\circ} \mathrm{C}$.

\section{Chemotaxonomic characteristics}

The predominant menaquinones of strains YU655$43^{\mathrm{T}}$ and YU793-41 were MK-10 $\left(\mathrm{H}_{4}\right)$ and MK-10 $\left(\mathrm{H}_{6}\right)$, with minor amounts of $\mathrm{MK}-10\left(\mathrm{H}_{8}\right)$. Strains YU438-5 and YU794-41 had major amounts of $\mathrm{MK}-10\left(\mathrm{H}_{8}\right)$ with $\mathrm{MK}-10\left(\mathrm{H}_{4}\right)$ and $\mathrm{MK}-10\left(\mathrm{H}_{6}\right)$. Isolates contained glucose, mannose, galactose, rhamnose, xylose, arabinose and 3-O-methylmannose as whole-cell sugars. The amino acids in the cell wall were 3-OH-diaminopimelic acid, alanine, glycine and glutamic acid (molar ratio, approx. $1: 1: 1: 1)$; this corresponds to murein type A1 $\gamma$ according to Schleifer \& Kandler (1972).
Mycolic acids were not detected. The glycan moiety of the murein contained glycolyl residues. Phosphatidylethanolamine was detected as a diagnostic phospholipid, but phosphatidylinositol, phosphatidylglycerol, phosphatidylcholine and an unidentified phospholipid containing glucosamine were not always detected.

The cellular fatty acids included iso-branched, anteisobranched, saturated and unsaturated fatty acids, corresponding to fatty acid pattern $2 \mathrm{~d}$ according to Kroppenstedt (1985). Isolate YU438-5 $5^{\mathrm{T}}$ contained diagnostic amounts of iso- $\mathrm{C}_{16: 0}$ and anteiso- $\mathrm{C}_{17: 0}$ $(>25 \%)$, while isolates YU655-43 ${ }^{\mathrm{T}}$, YU793-41 and YU794-41 contained relatively higher proportions of $\mathrm{C}_{15: 0}$ and $\mathrm{C}_{18: 1}$ with iso- $\mathrm{C}_{16: 0}$ and anteiso- $\mathrm{C}_{17: 0}$ (Table 2). The $\mathrm{G}+\mathrm{C}$ content of the DNA of the isolates ranged from $70 \cdot 7$ to $71.4 \mathrm{~mol} \%$.

\section{DNA-DNA hybridization}

Strain YU438-5 $5^{\mathrm{T}}$ exhibited levels of DNA-DNA relatedness of $12-20 \%$ with the other strains. DNA relatedness among strains YU655-43 ${ }^{\mathrm{T}}$, YU793-41 and YU794-41 was 40-60\%.

\section{Phylogenetic position}

Phylogenetic analysis of $16 \mathrm{~S}$ rDNA sequences revealed that the isolates fell within the cluster of the family Micromonosporaceae and represented a line of descent distinct from previously described actinomycetes of this family (Fig. 2). The $16 \mathrm{~S}$ rDNA signature nucleotides at positions 502-543 (A-U) and 1116-1184 (U-G) of isolates were different from those of the family Micromonosporaceae [positions 502-543 (G-C) and 1116-1184 (C-G)]. The closest neighbours of the isolates are members of the genus Dactylosporangium (similarity values from $95 \cdot 8$ to $97 \cdot 1 \%$ ). Strain YU438-5 had 98.7-98.9\% similarity to other isolates. The similarity values among strains YU655-43 ${ }^{\mathrm{T}}$, YU793-41 and YU794-41 were 99.7-99.9\%.

\section{DISCUSSION}

The family Micromonosporaceae currently consists of the genera Micromonospora, Actinoplanes, Dactylosporangium, Pilimelia, Catellatospora, Catenuloplanes, Couchioplanes, Spirilliplanes (Tamura et al., 1997) and Verrucosispora (Rheims et al., 1998), each having distinctive morphological features and/or chemotaxonomic characteristics. Micromonospora species form single spores on short or long sporophores; Actinoplanes, Dactylosporangium and Pilimelia species form sporangia; Catellatospora, Catenuloplanes, Couchioplanes and Spirilliplanes species form spore chains; Verrucosispora species do not form aerial mycelium or sporangia; Actinoplanes, Dactylo-

Fig. 2. Phylogenetic tree derived from $16 \mathrm{~S}$ rDNA sequences of isolates and members of the family Micromonosporaceae. Streptomyces ambofaciens ATCC $23877^{\top}$ (M27245) was used as the root organism. Scale bar $=0.01 K_{\text {nuc }}$. The numbers on the branches are confidence limits (expressed as percentages) estimated from a bootstrap analysis with 1000 replicates (only percentages above $50 \%$ are indicated). 
Table 3. Differential characteristics of the genus Virgosporangium and related genera

\begin{tabular}{|c|c|c|c|c|c|c|}
\hline Genus & $\begin{array}{c}\text { Spore } \\
\text { motility* }\end{array}$ & $\begin{array}{l}\text { Sporangium } \\
\text { formation* }\end{array}$ & $\begin{array}{c}\text { Fatty acid } \\
\text { type } \dagger\end{array}$ & $\begin{array}{c}\text { Cell wall } \\
\text { type }\end{array}$ & Major menaquinones & $\begin{array}{c}\text { Phospholipid } \\
\text { type } \S\end{array}$ \\
\hline Virgosporangium & + & + & $2 \mathrm{~d}$ & II & $\mathrm{MK}-10\left(\mathrm{H}_{4}, \mathrm{H}_{6}, \mathrm{H}_{8}\right)$ & PII \\
\hline Dactylosporangium & + & + & $3 b$ & II & MK-9 $\left(\mathrm{H}_{4}, \mathrm{H}_{6}, \mathrm{H}_{8}\right)$ & PII \\
\hline Actinoplanes & + & + & $2 \mathrm{~d}$ & II & MK-9 $\left(\mathrm{H}_{4}\right), 10\left(\mathrm{H}_{4}\right)$ & PII \\
\hline Spirilliplanes & + & - & $2 \mathrm{~d}$ & II & $\mathrm{MK}-10\left(\mathrm{H}_{4}\right)$ & PII \\
\hline Pilimelia & + & + & $2 d$ & II & MK-9 $\left(\mathrm{H}_{2}, \mathrm{H}_{4}\right)$ & PII \\
\hline Micromonospora & - & - & $3 b$ & II & MK-10( $\left.\mathrm{H}_{4}, \mathrm{H}_{6}\right), 9\left(\mathrm{H}_{4}, \mathrm{H}_{6}\right)$ & PII \\
\hline Catellatospora & - & - & ND & II & MK-10( $\left.\mathrm{H}_{8}, \mathrm{H}_{6}\right), 9\left(\mathrm{H}_{4}, \mathrm{H}_{6}\right)$ & PII \\
\hline Catenuloplanes & + & - & $2 \mathrm{c}$ & VI & MK-9 $\left(\mathrm{H}_{8}\right), 10\left(\mathrm{H}_{8}\right)$ & PII \\
\hline Couchioplanes & + & - & $2 \mathrm{c}$ & VI & MK-9( $\left(\mathrm{H}_{4}\right)$ & PIII \\
\hline
\end{tabular}

$*+$, Present; - , absent.

$\uparrow$ According to the classification of Kroppenstedt (1985). ND, Not determined.

$\$$ According to the classification of Lechevalier \& Lechevalier (1970).

$\S$ According to the classification of Lechevalier et al. (1977).

sporangium, Pilimelia, Catenuloplanes, Couchioplanes and Spirilliplanes spores show motility; Catenuloplanes and Couchioplanes species have lysine instead of mesodiaminopimelic acid as the diamino acid of the peptidoglycan.

Like most members of the family Micromonosporaceae, the isolates produced orange colonies on most media. They formed rod-shaped sporangia on short sporangiophores, which resembled the extended sporangia of the genus Dactylosporangium. Unlike members of the genus Dactylosporangium, however, which usually develop three to four spores per sporangium, the isolates developed rod-shaped sporangia with six or more spores. The isolates contained 3-OHdiaminopimelic acid as the diamino acid, and mesodiaminopimelic acid was not detected. Some members of the genera Micromonospora and Dactylosporangium are known to have 3-OH-diaminopimelic acid with meso-diaminopimelic acid in the cell wall. The isolates contained arabinose and xylose as diagnostic wholecell sugars, which corresponds to cell wall type II of Lechevalier \& Lechevalier (1970). The isolates also contained 3-O-methylmannose as a whole-cell sugar. Actinoplanes philippinensis, Dactylosporangium thailandense and Micromonospora chalcea were also found to have this sugar and Spirilliplanes yamanashiensis is known to have it (Tamura et al., 1997). Thus, most chemotaxonomic features are characteristic of the family Micromonosporaceae. The isolates were distinguished from the genus Dactylosporangium, their closest relatives based on 16S rDNA sequence data, by the absence of 10-methylated fatty acids and the presence of MK-10 $\left(\mathrm{H}_{4}, \mathrm{H}_{6}, \mathrm{H}_{8}\right)$. This combination of chemotaxonomic characteristics therefore distinguished the isolates from other members of the family Micromonosporaceae (Table 3). Phylogenetic analysis indicated that isolates belong to the family Micromonosporaceae and formed a compact cluster near the genus Dactylosporangium (Fig. 2). The robustness of this cluster was supported by a high bootstrap value $(100 \%)$.

On the basis of morphological, physiological, chemotaxonomic (Table 3) and phylogenetic criteria, strains YU438-5 ${ }^{\mathrm{T}}$, YU655-43 ${ }^{\mathrm{T}}$, YU793-41 and YU794-41 are readily distinguishable from the known actinomycetes mentioned above and warrant a new taxon. Strain YU438- $5^{\mathrm{T}}$ is considered to represent a distinct species based on DNA-DNA hybridization, cellular fatty acid proportion and lack of growth at $37^{\circ} \mathrm{C}$. We propose that the isolates be classified in a new genus, Virgosporangium gen. nov., with the type species Virgosporangium ochraceum sp. nov. for strains YU655-43 ${ }^{\mathrm{T}}\left(=\mathrm{IFO} 16418^{\mathrm{T}}=\mathrm{JCM} 11001^{\mathrm{T}}\right)$, YU793-41 (= IFO 16419) and YU794-41 (= IFO 16420 ), and Virgosporangium aurantiacum sp. nov. for strain YU438-5 $5^{\mathrm{T}}\left(=\mathrm{IFO} 16421^{\mathrm{T}}=\mathrm{JCM} 11002^{\mathrm{T}}\right)$.

The genus Virgosporangium should be considered as a member of the family Micromonosporaceae Stackebrandt et al. 1997 on the basis of the comparative analysis of $16 \mathrm{~S}$ rRNA sequences described here.

\section{Description of Virgosporangium gen. nov.}

Virgosporangium (Vir.go.spo.ran'gi.um. Gr. n. virga rod; Gr. n. spora a seed, spore; Gr. n. argeion vessel; M.L. neut. n. Virgosporangium an organism with rodshaped, spore-containing vessels, i.e. sporangia).

Cells are Gram-positive, non-acid-fast, aerobic organisms with branching hyphae. Non-fragmentary substrate mycelia are present. Slender sporangia are formed on short sporangiophores on the substrate mycelium. Each sporangium typically contains a single row of six or more spores. Spores are oval or short rods $(0.6-0.9$ by $0.8-1 \cdot 5 \mu \mathrm{m})$ and exhibit motility. Strictly aerobic. Good growth occurs between 20 and $30^{\circ} \mathrm{C}$. In general, the vegetative mycelia are yellow to orange. Cell walls contain glutamic acid, glycine, alanine and 
3-OH-diaminopimelic acid. Wall chemotype is II according to Lechevalier \& Lechevalier (1970), and the peptidoglycan type is presumed to be $\mathrm{A} 1 \gamma$ according to Schleifer \& Kandler (1972). Mannose, 3-O-methylmannose, rhamnose, glucose, arabinose, xylose and galactose are detected as whole-cell sugars. The major cellular fatty acid is anteiso- $\mathrm{C}_{17: 0}$. The major menaquinones are MK-10 $\left(\mathrm{H}_{4}\right)$ and MK-10( $\left.\mathrm{H}_{6}\right)$. Phosphatidylethanolamine is present as the diagnostic phospholipid (phospholipid pattern type PII). The acyl type of cell wall polysaccharide is glycolyl. Mycolic acid is not detected. The $\mathrm{G}+\mathrm{C}$ content of DNA is $71 \mathrm{~mol} \%$. Habitat is soil. The type species is Virgosporangium ochraceum.

\section{Description of Virgosporangium ochraceum sp. nov.}

Virgosporangium ochraceum (och.ra'ce.um. M.L. neut. adj. ochraceum rust-coloured).

Morphological, chemotaxonomic and general characteristics are as given above for the genus. Brownish soluble pigment is produced on tyrosine agar (ISP medium 7). Gelatin liquefaction is negative. Hydrolyses starch. Does not decompose calcium malate. Coagulation and peptonization of milk are positive. Optimum temperature for growth is $15-30{ }^{\circ} \mathrm{C}$. Grows at $37^{\circ} \mathrm{C}$. Does not grow on $7 \% \mathrm{NaCl}$. Glucose, Dfructose, D-xylose, L-arabinose, glycerol and mannose are utilized, but inulin is not. The major cellular fatty acids are iso- $\mathrm{C}_{15: 0}$, iso- $\mathrm{C}_{16: 0}, \mathrm{C}_{17: 0}$ and $\mathrm{C}_{18: 1}$ with anteiso- $\mathrm{C}_{17: 0}$. The $\mathrm{G}+\mathrm{C}$ content of DNA is $71 \mathrm{~mol} \%$. Habitat is soil. The type strain is YU655-43 $3^{\mathrm{T}}(=\mathrm{IFO}$ $16418^{\mathrm{T}}=\mathrm{JCM} 11001^{\mathrm{T}}$ ).

\section{Description of Virgosporangium aurantiacum sp. nov.}

Virgosporangium aurantiacum (au.ran.ti'ac.um. M.L. neut. adj. aurantiacum orange-coloured).

Morphological, chemotaxonomic and general characteristics are as given above for the genus. Brownish soluble pigment is produced on tyrosine agar (ISP medium 7). Gelatin liquefaction is negative. Hydrolyses starch. Does not decompose calcium malate. Coagulation and clearing of milk are positive. Optimum temperature for growth is $15-30^{\circ} \mathrm{C}$. Does not grow at $37^{\circ} \mathrm{C}$. Does not grow on $4 \% \mathrm{NaCl}$. Glucose, D-fructose, D-xylose, L-arabinose, glycerol, maltose and mannose are utilized, but inositol, D-sorbitol and inulin are not. The major cellular fatty acids are iso$\mathrm{C}_{16: 0}$ with anteiso- $\mathrm{C}_{17: 0}$. The $\mathrm{G}+\mathrm{C}$ content of DNA is $71 \mathrm{~mol} \%$. Habitat is soil. The type strain is YU438-5 $\left(=\mathrm{IFO} 16421^{\mathrm{T}}=\mathrm{JCM} 11002^{\mathrm{T}}\right)$.

\section{REFERENCES}

Asano, K. \& Kawamoto, I. (1986). Catellatospora, a new genus of the Actinomycetales. Int J Syst Bacteriol 36, 512-517.

Ezaki, T., Hashimoto, Y., Takeuchi, N., Yamamoto, H., Liu, S.-L.,
Miura, H., Matsui, K. \& Yabuuchi, E. (1988). Simple genetic identification method of viridans group streptococci by colorimetric dot hybridization and quantitative fluorometric hybridization in microdilution wells. J Clin Microbiol 26, 1708-1713.

Ezaki, T., Hashimoto, Y. \& Yabuuchi, E. (1989). Fluorometric deoxyribonucleic acid-deoxyribonucleic acid hybridization in microdilution wells as an alternative to membrane filter hybridization in which radioisotopes are used to determine genetic relatedness among bacterial strains. Int J Syst Bacteriol 39, 224-229.

Ezaki, T., Saidi, S. M., Liu, S. L., Hashimoto, Y., Yamamoto, H. \& Yabuuchi, E. (1990). Rapid procedure to determine the DNA base composition from small amounts of Gram-positive bacteria. FEMS Microbiol Lett 67, 127-130.

Felsenstein, J. (1985). Confidence limits on phylogenies: an approach using the bootstrap. Evolution 39, 783-791.

Goodfellow, M., Stanton, L. J., Simpson, K. E. \& Minnikin, D. E. (1990). Numerical and chemical classification of Actinoplanes and some related actinomycetes. J Gen Microbiol 136, 19-36.

Hayakawa, M. \& Nonomura, H. (1987). Humic acid-vitamin agar, a new medium for selective isolation of soil actinomycetes. $J$ Ferment Technol 65, 501-509.

Hayakawa, M., Tamura, T. \& Nonomura, H. (1992). Selective isolation of Actinoplanes and Dactylosporangium from soil by using g-collidine as the chemoattractant. J Ferment Bioeng 72, 426-432.

Kimura, M. (1980). A simple method for estimating evolutionary rates of base substitutions through comparative studies of nucleotide sequences. $J$ Mol Evol 16, 111-120.

Koch, C., Kroppenstedt, R. M., Rainey, F. A. \& Stackebrandt, E. (1996). 16S ribosomal DNA analysis of the genera Micromonospora, Actinoplanes, Catellatospora, Catenuloplanes, Couchioplanes, Dactylosporangium, and Pilimelia and emendation of the family Micromonosporaceae. Int $J$ Syst Bacteriol 46, 765-768.

Krasil'nikov, N. A. (1938). Ray Fungi and Related Organisms Actinomycetales. Moscow: Izdatel'stvo Akademii Nauk SSSR.

Kroppenstedt, R. M. (1985). Fatty acid and menaquinone analysis of actinomycetes and related organisms. In Chemical Methods in Bacterial Systematics, pp. 173-199. Edited by M. Goodfellow \& D. E. Minnikin. London: Academic Press.

Lechevalier, M. P. \& Lechevalier, H. A. (1970). Chemical composition as a criterion in the classification of aerobic actinomycetes. Int J Syst Bacteriol 20, 435-443.

Lechevalier, M. P., DeBievre, C. \& Lechevalier, H. A. (1977). Chemotaxonomy of aerobic actinomycetes: phospholipid composition. Biochem Syst Ecol 5, 249-260.

Mesbah, M., Premachandran, U. \& Whitman, W. B. (1989). Precise measurement of the $\mathrm{G}+\mathrm{C}$ content of deoxyribonucleic acid by high-performance liquid chromatography. Int $J$ Syst Bacteriol 39, 159-167.

Palleroni, N. J. (1980). A chemotactic method for the isolation of Actinoplanaceae. Arch Microbiol 128, 53-55.

Pernodet, J.-L., Boccard, F., Alegre, M.-T., Gagnat, J. \& Guérineau, M. (1989). Organization and nucleotide sequence analysis of a ribosomal RNA gene cluster from Streptomyces ambofaciens. Gene 79, 33-46.

Perrière, G. \& Gouy, M. (1996). WWW-Query: an on-line retrieval system for biological sequence banks. Biochimie 78, 364-369.

Rayner, R. W. (1970). A Mycological Colour Chart. Kew, Surrey: Commonwealth Mycological Institute. 
Rheims, H., Schumann, P., Rohde, M. \& Stackebrandt, E. (1998). Verrucosispora gifhornensis gen. nov., sp. nov., a new member of the actinobacterial family Micromonosporaceae. Int J Syst Bacteriol 48, 1119-1127.

Saitou, N. \& Nei, M. (1987). The neighbor-joining method: a new method for reconstructing phylogenetic trees. Mol Biol Evol 4, 406-425.

Schleifer, K. H. \& Kandler, O. (1972). Peptidoglycan types of bacterial cell walls and their taxonomic implications. Bacteriol Rev 36, 407-477.

Seino, A., Arai, M., Enokida, R., Okazaki, T. \& Furuichi, A. (1985). Identification Manual of Actinomycetes. Tokyo: The Society for Actinomycetes Japan.

Shirling, E. B. \& Gottlieb, D. (1966). Methods for characterization of Streptomyces species. Int J Syst Bacteriol 16, 313-340.

Stackebrandt, E., Rainey, F. A. \& Ward-Rainey, N. L. (1997). Proposal for a new hierarchic classification system, Actinobacteria classis nov. Int J Syst Bacteriol 47, 479-491.

Tamura, T., Nakagaito, Y., Nishii, T., Hasegawa, T., Stackebrandt, E. \& Yokota, A. (1994). A new genus of the order Actinomycetales, Couchioplanes gen. nov., with descriptions of Couchioplanes caeruleus (Horan and Brodsky 1986) comb. nov. and Couchio- planes caeruleus subsp. azureus subsp. nov. Int $J$ Syst Bacteriol 44, 193-203.

Tamura, T., Hayakawa, M. \& Hatano, K. (1997). A new genus of the order Actinomycetales, Spirilliplanes gen. nov., with description of Spirilliplanes yamanashiensis sp. nov. Int J Syst Bacteriol 47, 97-102.

Tamura, T., Hayakawa, M. \& Hatano, K. (1998). A new genus of the order Actinomycetales, Cryptosporangium gen. nov., with descriptions of Cryptosporangium aridum sp. nov. and Cryptosporangium yamanashiensis sp. nov. Int J Syst Bacteriol 48, 995-1005.

Tamura, T., Hayakawa, M. \& Hatano, K. (1999). Sporichthya brevicatena sp. nov. Int J Syst Bacteriol 49, 1779-1784.

Thompson, J. D., Higgins, D. G. \& Gibson, T. J. (1994). CLUSTAL $\mathrm{W}$ : improving the sensitivity of progressive multiple sequence alignment through sequence weighting, position-specific gap penalties and weight matrix choice. Nucleic Acids Res 22, 4673-4680.

Yokota, A., Tamura, T., Hasegawa, T. \& Huang, L. H. (1993). Catenuloplanes japonicus gen. nov., sp. nov., nom. rev., a new genus of the order Actinomycetales. Int J Syst Bacteriol 43, $805-812$. 